\title{
OS TIMBIRAS: O POEMA QUE PODIA TER SIDO E QUE NÃO FOI*
}

\section{OS TIMBIRAS: A FAILED PROJECT}

Roberto Acízelo de Souza ${ }^{1}$

\begin{abstract}
Resumo: Os timbiras, de Gonçalves Dias, por sua condição de poema que restou incompleto, é analisado tendo em vista sua concepção original, as circunstâncias de sua publicação e o estágio de elaboração em que então se encontrava. Estudam-se ainda sua fortuna crítica e as motivações e consequências da opção do autor pela forma da epopeia.
\end{abstract}

Palavras-chave: Romantismo; modernidade; epopeia.

Abstract: Os timbiras, by Gonçalves Dias, due to its condition of a poem that remained incomplete, is analysed taking into account its original conception, the circunstances in which it was published and the stage of elaboration it was when printed. Its critical reception, as well as the motivations and consequences of the author's option for the epic form, are also studied.

Keywords: Romanticism; modernity; epic.

O estudo crítico-analítico de composições literárias incompletas impõe, por motivos evidentes, a obtenção de dados preliminares relativos à sua concepção inicial, bem como às circunstâncias de sua publicação e ao estágio de elaboração em que então se encontravam. No caso de Os timbiras, há fontes de informação suficientes para um esclarecimento satisfatório dessas questões. Vejamos.

O poeta cogitava escrever a obra já em 1844, conforme declara em carta a um amigo:

Ando a estudar para compor um Poema - é por agora - a 'minha obra'. Quero fazer uma cousa exclusivamente americana - exclusivamente nossa - eu o farei talvez - já que todo mundo hoje se mete a inovar - também eu pretendo inovar - inovarei - criarei alguma cousa que espero em Deus, os nossos não esquecerão. (apud Bandeira, 1952, p. 81-82).

Três anos depois, já tinha principiado a redigir o texto, cujo plano expõe a outro amigo, com humor e auto-ironia:

Imaginei um poema... como nunca ouviste falar de outro: magotes de tigres, de quatis, de cascavéis; imaginei mangueiras e jabuticabeiras copadas, jequitibás e ipês arrogantes, sapucaieiras e jambeiros, de palmeiras nem falemos; guerreiros diabólicos, mulheres feiticeiras, sapos e jacarés sem conta: enfim, um gênese americano, uma Ilíada brasileira, uma criação recriada. Passa-se a ação no Maranhão e vai terminar no Amazonas com a dispersão dos timbiras; guerras entre eles e depois com os portugueses. O primeiro canto já está pronto, o segundo começado. (apud Bandeira, 1952, p. 81).

\footnotetext{
* Versão integral de texto apresentado na Seção 6 (Narrativa épica e modernidade) do $13^{\circ}$ Congresso Alemão de Lusitanistas, realizado de 11 a 14 de setembro de 2020 na Universidade de Augsburg.

${ }^{1}$ Universidade Estadual do Rio de Janeiro - UERJ, Rio de Janeiro, Rio de Janeiro, Brasil; https://orcid.org/00000003-0607-5911; acizelo@bighost.com.br
} 
Foi prosseguindo no projeto, provavelmente com intermitências, tanto que, em 1851, durante viagem de estudos que fez ao Maranhão e à Amazônia, aproveitou para colher material visando continuar a composição do poema, segundo informa seu amigo e primeiro biógrafo, Antônio Henriques Leal (cf. 1874, p. 282).

A publicação, restrita aos quatro primeiros cantos, ocorreu em 1857. Constitui sinal claro de que o poeta tinha a intenção de arrematar a obra o fato de que, conforme o mesmo Henriques Leal (ibid., p. 282), persistiu na busca de subsídios para a execução do seu plano, durante as novas viagens que empreendeu às "províncias do norte", de 1859 a 1861 . E tais esforços não seriam em vão, pois o biógrafo declara que, dos dezesseis cantos planejados, "vi[u] em 1853 doze, já copiados a limpo", e que, em outubro de 1857, o poeta lhe fez a leitura de seis deles. E acrescenta:

[...] noutras ocasiões, principalmente quando esteve comigo no Maranhão em 1861, faloume dele [do poema], como quem já o houvesse concluído, faltando-lhe apenas as modificações que pretendia fazer-lhe depois de sua visita às regiões amazônicas, onde os indígenas aproximavam-se de seu estado primitivo. (ibid., p. 282).

O motivo por que se decidira a publicar o poema antes de sua conclusão explicou o autor em uma carta dirigida a pessoa do seu círculo: "Se a coisa não tem de merecer aceitação, não vale a pena gastar a minha vida preocupado com essa ideia: assim, publico em folheto, para dar continuação depois. Se for aceito, cobrarei alma nova para a continuação; se não, tomo naturalmente outro caminho" (apud Bandeira, 1952, p. 137). ${ }^{2}$

Antônio Henriques Leal (1874, p. 282-283), no entanto, vê na estratégia de publicação fragmentária do poema razões bem diferentes das alegadas por Gonçalves Dias. Não as comprova, porém, com pronunciamentos do próprio poeta, propondo-as como parte de sua resposta à crítica devastadora que Bernardo Guimarães fizera à obra:

[...] não [...] pretend[ia] publicar [os cantos do poema] senão em fragmentos, como praticara lord Byron com o D. Juan, ou como Goethe, que consumiu vinte e quatro anos para concluir o Fausto. Foi levado de igual pensamento e para ouvir e aproveitar os conselhos e alvitres da crítica ilustrada e desapaixonada e conhecer a impressão que causaria no público [...] obra de tanto momento que deu à estampa os cantos que conhecemos. Só depois disto é que reuniria em volume o poema completo, retocado, limado e conforme ao que lhe apontassem de mais sensato e melhor. ${ }^{3}$

\footnotetext{
${ }^{2}$ Lúcia Miguel-Pereira (1943, p. 128) levanta a hipótese de que o fato de ter sido negativo o resultado do teste de público a que o autor submeteu os quatro primeiros cantos poderia ter constituído uma das razões para sua desistência de continuar a composição: "Grande deve ter sido a decepção de Gonçalves Dias, então no auge da fama, diante do frio acolhimento do poema, que, ao compor, não hesitara - à puridade, é certo - em chamar 'Ilíada americana'. Talvez isso tenha concorrido para que não o concluísse." Na verdade, porém, o poeta não se convenceu da fraqueza do poema pela indiferença com que foi recebida a publicação de parte dele, tanto que, em carta dirigida ao sogro, atribuiu o desinteresse pela obra não a deficiências que apresentasse, mas ao pouco apreço dos brasileiros pela leitura: "Conheço a nossa gente, e sei que eles estão procurando pretexto para não lerem. O não estar a cousa completa será para eles boa desculpa. Como eles quiserem, que também não se me dá muito disso" (apud Bandeira, 1952, p. 137-138). Mas, como veremos, não é seguro que o poema não tenha sido concluído, tampouco é certo que a frieza de sua recepção tenha contribuído para o abandono do projeto.

${ }^{3} \mathrm{Na}$ sequência do trecho transcrito, afirma Leal (ibid., p. 283): "Enganam-se, portanto, aqueles que atribuem a aparição desses quatro cantos à sofreguidão de celebridade, quando já a tinha ele [Gonçalves Dias] em demasia para sua desambiciosa modéstia". Em outro trecho do livro, especifica o destinatário de sua réplica: "Tendo em outro lugar apresentado os motivos que levaram Gonçalves Dias a publicar esse fragmento [...], dispenso de refutar tão falsas proposições [...]. Engana-se nisso o ilustre autor dos Cantos da solidão [isto é, Bernardo Guimarães]" (ibid., p. 314-315). No entanto, o escritor mineiro condena não o fato de o texto ter sido publicado incompleto,
}

Rev. Bras. Lit. Comp. Niterói, v. 22, n. 40, pp. 56-72, mai. /ago. 2020 
Até, portanto, 1861, os documentos disponíveis nos permitem acompanhar os desdobramentos dos planos de Gonçalves Dias quanto a Os timbiras. Daí por diante, porém, só nos resta deduzir e formular hipóteses.

Uma possibilidade é que, não obstante o desânimo com a vida literária que o poeta manifesta já em 1850, na carta-dedicatória que abre o volume dos seus Últimos cantos, ${ }^{4} \mathrm{o}$ abandono do projeto se teria dado somente a partir de 1862, pois, como vimos, no ano anterior ele ainda confidenciara a Henriques Leal seu empenho em concluir o poema. É que, desde então, não teria mais sossego na vida, com a saúde gravemente comprometida, o desfecho de uma crise conjugal que se arrastava e até certa instabilidade na investidura das comissões oficiais de pesquisa que o governo imperial costumava atribuir-lhe, o que muito lhe fragilizava as finanças.

Pode ser, porém, que tivesse persistido na ideia de publicar o poema até o fim da vida. Depõem a favor dessa hipótese duas circunstâncias: na referida carta-dedicatória de 1850, embora declare em extinção a "fé e o entusiasmo [...] que alumia[vam] [suas] composições", também afirma que "por mais algum tempo continuar[ia] [na luta], variando apenas o sentido dos [seus] cantos" (Dias, 1959, p. 352); e consta que manuscritos seus - entre os quais não chega a ser implausível que estivessem os cantos inéditos de Os timbiras - perderam-se no naufrágio de que foi vítima. ${ }^{5}$

Assim, dos primeiros lampejos sobre a composição, em 1844, até sua morte, em 1864, ou, segundo a outra hipótese aventada, até o abandono definitivo do projeto, que terá ocorrido, como vimos, por volta de 1862, o poeta, se não "gast[ou] [...] a vida preocupado com essa ideia", a ela dedicou em torno de vinte ou dezoito anos, o que não é pouco para uma existência de quarenta e um. É plausível, pois, o que afirma Henriques Leal (1874, p. 281-282) sobre a grande frustação que lhe terá causado deixar inconclusa a epopeia que concebera:

[...] uma vez completo e concluído esse poema épico, seria a joia mais valiosa de sua esplendente coroa, fechando, assim, como pretendia, o mirífico ciclo de suas composições poéticas com tão soberbo troféu.

mas a privação de senso autocrítico que teria levado o autor a escrevê-lo: “A razão por que [...] a musa do Sr. Gonçalves Dias [...] veio a rastejar tanto n'Os timbiras nos presumimos ser a seguinte: O poeta vendo seus Cantos geralmente aplaudidos, sem que se lhes fizesse a menor censura [...], vendo seu nome apregoado como o de um poeta original, grande e de primeira força, assentou que tudo que caísse do bico de sua pena era belo, precioso" ([Guimarães], 1859d, p. 3). Por sinal, exatos cem anos após a crítica de Bernardo Guimarães, Antônio Cândido (1971 [1959], v. 2, p. 96), que também faria mau juízo do poema, supõe que o poeta acabou não o publicando exatamente por autocrítica: "Ele próprio [Gonçalves Dias] deve ter percebido que não era bom o nível da obra, pois tendo vivido ainda sete anos depois da edição de Leipzig [a primeira e única publicação parcial da obra], e tendo composto [...] doze dos dezesseis cantos programados, não os quis publicar [...]".

4 "No meio de rudes trabalhos, de ocupações estéreis, de cuidados pungentes, - inquieto do presente, incerto do futuro, derramando um olhar de lágrimas e de saudades sobre o meu passado - percorri este primeiro estádio da minha vida literária. [...] Entrei na luta, e por mais algum tempo continuarei nela, variando apenas o sentido dos meus cantos. A fé e o entusiasmo, o óleo e o pábulo da lâmpada que alumia as composições do artista, vão-se-me esfriando dentro do peito; eu o conheço e sinto [...]" (Dias, 1959, p. 351-352).

${ }^{5}$ Antônio Henriques Leal (1874, p. 182-186) relata os esforços que fez para reaver certa "pequena mala de couro que [Gonçalves Dias] muito zelava, trazendo pendurada ao pescoço a chave dela", referida pelo tripulante que servia o poeta na cabine do navio. Informa tê-la rastreado por anos, sem a encontrar, tendo apenas apurado, por um indivíduo que chegou a ver a mala, que nela havia livros e manuscritos, um dos quais com o título de "A noiva de Messina", tradução de Schiller empreendida pelo poeta desde por volta de 1857-1858, e enfim publicada no v. 5 das Obras póstumas (1867), mas cuja versão definitiva, provavelmente essa que estaria na tal mala, se perdeu. Nenhuma menção, pois, ao manuscrito de Os timbiras. Lúcia Miguel-Pereira (1942, p. 88), contudo, é taxativa: afirma que o poema não foi terminado, e que os cantos não publicados “[...] perderam-se, certamente, no naufrágio do Ville de Boulogne". Antônio Cândido (1971 [1959], p. 96), por sua vez, conclui o subcapítulo que dedica à análise do poema com uma suposição que parece não ter outra função senão dar um fecho algo "literário" ao seu texto: “[...] não consta haver [Gonçalves Dias] terminado o poema, cuja parte inédita teria desaparecido na tragédia do Ville de Boulogne".

Rev. Bras. Lit. Comp. Niterói, v. 22, n. 40, pp. 56-72, mai. /ago. 2020

https://doi.org/10.1590/2596-304X20202240ras 
Era nela que librava suas mais alentadas esperanças, e tendo para si que seu poema firmaria ainda mais sua reputação, [...] tencionava dar-lhe todo o desenvolvimento possível no que respeitava ao caráter, usos, costumes, superstições e lendas dos nossos indígenas, descrevendo ao mesmo tempo quanto há de maravilhoso e magnificente na natureza brasileira - nos seus rios, nos seus lagos, nas suas montanhas, na sua flora e na sua fauna $[\ldots] .^{6}$

Ora, considerando esse conjunto de suposições e indícios, inclinamo-nos a dar crédito ao testemunho de Antônio Henriques Leal, biógrafo acatado pelo rigor das pesquisas documentais que lastreiam seus escritos. Assim, julgamos que Gonçalves Dias efetivamente escreveu pelo menos os doze cantos do poema que Henriques Leal declara ter visto na posse do poeta em 1853. Os quatro restantes para a integralização do texto, é bem razoável supor que os tenha composto ao longo dos onze anos de vida que o destino ainda lhe reservava. Não chega a ser, pois, excesso de imaginação acreditar que o poeta trouxesse consigo da Europa, em 1864, na sua viagem de volta à terra natal, o manuscrito completo de $O$ s timbiras pronto para publicação, o qual teria ou desaparecido no naufrágio, ou se extraviado depois, com o sumiço da mala em que provavelmente estava guardado.

Seja lá como for, a circunstância de o poema ter ficado inconcluso determinou, como era de esperar, uma recepção crítica rarefeita. Vamos percorrê-la, concentrando-nos nas poucas fontes que se ocuparam mais especificamente com o texto.

As primeiras avaliações surgem logo após a publicação da obra (em 1857, portanto), sendo irrestritamente laudatórias. Com os critérios para juízos críticos sobre lançamentos literários próprios da época - intensidade do compromisso nacionalista e da fidelidade à cor local -, Joaquim Manuel de Macedo e Francisco Otaviano, em folhetins mais noticiosos do que analíticos, limitam-se a exaltar as qualidades do autor e do poema. ${ }^{7}$ Dois anos mais tarde, porém, Bernardo Guimarães empreende, com os mesmos critérios, comentários propriamente analíticos, numa série de quatro folhetins. ${ }^{8}$ Seu julgamento contrasta por completo com as impressões de Macedo e Otaviano, pois, para o autor mineiro, a obra constitui fracasso absoluto, pelos muitos defeitos de língua e métrica que apresentaria. ${ }^{9}$

\footnotetext{
${ }^{6}$ Antônio Cândido, como vimos (cf. nota 2), formula suposição diametralmente oposta sobre o juízo do poeta a propósito da obra, que não teria passado por seu crivo crítico, tanto que não teria querido publicar os demais cantos que chegou a compor.

${ }^{7}$ Os folhetins, na verdade, não vêm assinados, mas tanto Antônio Henriques Leal (1874, p. 469-470) como Manuel Bandeira (1952, p. 138) asseveram que seus autores são respectivamente Macedo e Otaviano.

${ }^{8}$ Já nos referimos a essa avaliação crítica, ao citarmos o trecho em que Antônio Henriques Leal defende seu ponto de vista sobre os motivos que teriam levado Gonçalves Dias à publicação fragmentária do poema. Bandeira (1952, p. 138) assinala que a série de artigos que a constitui foi publicada anonimamente, o que é verdade, mas várias fontes - Basílio Magalhães, na sua obra Bernardo Guimarães, biografia publicada em 1926, e os bibliógrafos Inocêncio Francisco da Silva (v. 8 do Dicionário bibliográfico português [1867]) e Sacramento Blake (v. 1 do Dicionário bibliográfico brasileiro [1883]) - informam que os textos são de fato da autoria de Bernardo Guimarães. De resto, o próprio Antônio Henriques Leal assevera ser Bernardo Guimarães o autor da crítica em questão (ver nota 2).

${ }^{9}$ Segundo Bandeira (1952, p. 138), no entanto, “[a] crítica deixava mal não o poeta, mas o crítico", por ser "dura e injusta". Anos depois, porém, Bernardo Guimarães escreveria uma longa elegia intitulada "À morte de Gonçalves Dias", publicada no volume $O$ índio Afonso (1873) e datada de “Ouro Preto, outono de 1869”. O texto foi incluído posteriormente nas Poesias completas de Bernardo Guimarães (Rio de Janeiro: INL, 1959), organizadas por Alphonsus de Guimaraens Filho, e acompanhado de nota na qual se lê: "O poema foi escrito cinco anos depois da morte de Gonçalves Dias, e nele Bernardo Guimarães protesta contra o fato de ter o Congresso recusado a sua participação em homenagem que visava erguer um monumento ao poeta da 'Canção do exílio'. Daí a linguagem candente que usa: 'Esses, que às pátrias glórias refratários / De um nobre povo creem-se mandatários...” (p. 511).
}

Rev. Bras. Lit. Comp. Niterói, v. 22, n. 40, pp. 56-72, mai. /ago. 2020

https://doi.org/10.1590/2596-304X20202240ras 
No período romântico, além dessas considerações jornalísticas, feitas, como diz Bernardo Guimarães (1859b, p. 2), "ao correr da pena", seguem-se, no âmbito propício a considerações mais meditadas constituído pelos tratados de história da literatura, estudos sobre a poesia de Gonçalves Dias.

Assim, Fernandes Pinheiro, tanto no Curso elementar de literatura nacional (1862) como no Resumo de história literária (1873), inclui Gonçalves Dias entre os poetas que estuda, sendo bastante elogioso em seus juízos, exceto pelo reparo que faz ao que chama "mal entendido americanismo", que consistiria no emprego de palavras como boré, tacape, piaga, manitô, maracá, anhangá, no seu parecer "neologismos bárbaros e quiçá antieufônicos", que estariam "adulterando o opulento idioma português [...], língua dos nossos avós" (Pinheiro, 1873, p. 457). Não se refere a Os timbiras no Curso, mas, no Resumo, reserva-lhe dois parágrafos entusiásticos, afirmando que, em função de "tantas maravilhas" que havia no poema "chega-se a acreditar que talvez fosse esse o verdadeiro tipo da moderna epopeia brasílica" (ibid., p. 460). ${ }^{10}$

Ferdinand Wolf, por sua vez, em $O$ Brasil literário, dedica algumas páginas a Gonçalves Dias. Quanto a Os timbiras, o historiador austríaco reconhece "[o] talento do poeta [...] na beleza dos versos e na dicção como em numerosos detalhes" (1955 [1863], p. 267), mas, por motivos evidentemente determinados por suas notórias relações de amizade com Gonçalves de Magalhães e mesmo com D. Pedro II, considera o poema inferior à Confederação dos Tamoios, por não ter tomado, diferentemente do que teria feito Magalhães, "um acontecimento histórico de grande alcance, [que permitisse] ressaltar o contraste da vida e dos costumes índios com as qualidades e os defeitos da civilização dos brancos [...]" (ibid., p. 267). De resto, o ponto de vista de Wolf sobre o poema é, como diríamos hoje, sumamente eurocêntrico, a ponto de ele estranhar - e censurar - o radical "americanismo" de Gonçalves Dias: "Esta predileção por tudo o que é indígena de tal modo tocou o poeta que ele queixa-se de a América ter entrado em comunicação com a Europa, e não vê mais que os maus lados da civilização que vem deste continente" (ibid., p. 267). Trata-se, ainda que com claro viés de reprovação, do primeiro reconhecimento do caráter crítico que assinala o indianismo gonçalvino, bem distinto da orientação adotada por José de Alencar em suas criações indianistas, que apresentam as relações entre as "raças" indígena e europeia não como um choque de civilizações, mas como uma espécie de encontro providencial. ${ }^{11}$

\footnotetext{
${ }^{10}$ Estranhamente, Fernandes Pinheiro (1873, p. 460) apõe a seguinte nota ao primeiro desses parágrafos: “Os fragmentos existentes desse poema foram incorporados à 5. ${ }^{a}$ edição das suas Poesias, impressas em Paris (1870) e editoradas pelo Sr. B. L. Garnier". Erros do autor: como vimos, os quatro cantos conhecidos de Os timbiras saíram em volume específico, no ano de 1857; e a edição das Poesias por ele mencionada de fato datam de 1870 e foram "editoradas pelo Sr. B. L. Garnier", porém impressas não em Paris, e sim no Rio de Janeiro. Assim, ao que parece, tendo tomado conhecimento do poema somente por sua edição de 1870, Fernandes Pinheiro naturalmente não podia mencioná-lo no Curso, que foi publicado em 1862.

${ }^{11}$ Essa questão da existência de matizes distintos no indianismo romântico brasileiro ainda nos parece pouco estudada. Alfredo Bosi (1970, p. 116), por exemplo, afirma o seguinte: "Para a primeira geração romântica [...], presa a esquemas conservadores, a imagem do índio casava-se sem traumas com a glória do colono que se fizera brasileiro, senhor cristão de suas terras e desejoso de antigos brasões. É a perspectiva de Gonçalves Dias até à sua última produção indianista, Os timbiras [...]." Ora, a assertiva vale para José de Alencar, mas de modo algum para Gonçalves Dias, cuja produção indianista ressalta a tragédia da conquista, e não o congraçamento de raças, e cujos "excessos" americanistas não sem razão foram notados por Ferdinand Wolf. Fritz Ackerman (1964 [1938], p. 114) percebeu esse traço do indianismo gonçalvino, a que chama "pessimismo cultural”. Perceberam-no também Haroldo Paranhos (1937, p. 103) - "Condenando os processos da colonização portuguesa adotados no Brasil, o ilustre maranhense levanta a voz em defesa dos índios, vítimas da cobiça e da ganância dos lusos, e ainda por cima malsinados, injuriados e martirizados pelos conquistadores d'além-mar." - e José Aderaldo Castello (1999, p. 228): "[Gonçalves Dias] não glorificou a síntese étnica, o surgimento do brasileiro. Se o processo de miscigenação fica entrevisto [na sua obra], o poeta acentua, porém, a reação por parte do índio [...].” David Treece (2008 [2000]), por sua vez, também reconhece essa particularidade do poeta maranhense, que se extremou da concepção hegemônica segundo a qual a integração das nações ameríndias à sociedade brasileira teria sido consentida, num processo ameno e de final feliz. Desse modo, a demonstração feita por Wilton José Marques (2010) de que
}

Rev. Bras. Lit. Comp. Niterói, v. 22, n. 40, pp. 56-72, mai. /ago. 2020

https://doi.org/10.1590/2596-304X20202240ras 
Sotero dos Reis, por fim, nos volumes 4 e 5 de seu Curso de literatura portuguesa $e$ brasileira, publicados respectivamente em 1868 e 1873, consagra amplo espaço a Gonçalves Dias, dedicando-lhe sete lições, uma das quais - a lição LXXXIV (v. 4) - se ocupa inteiramente com Os timbiras. O autor, não obstante assinalar o caráter incompleto do poema, só faz elogiálo, como, de resto, era de esperar, dada a generosidade com que o maranhense Sotero trata todos os comprovincianos que estuda na obra, especialmente - caso de Gonçalves Dias - os que integraram o grupo literário de que fez parte, chamado por Sílvio Romero "escola maranhense".

Para concluir o inventário dessas avaliações oitocentistas, lembremos que Machado de Assis, nos seus principais ensaios críticos da década de 1870 - "Notícia da atual literatura brasileira: instinto de nacionalidade" (1873) e "A nova geração" (1879) -, ambos, como se sabe, de cunho panorâmico, não centrados em autor ou obra específicos, faz considerações sobre Gonçalves Dias. Conforme os objetivos desses estudos, trata-se não propriamente de análises, mas de menções sumárias, e sobriamente elogiosas, com destaque especial para $O s$ timbiras. ${ }^{12}$

Um segundo tempo da recepção crítica de Gonçalves Dias inaugura-se com Sílvio Romero. A partir dele, com o "critério etnográfico", cuja introdução nos estudos da literatura nacional ele credita a si mesmo (cf. Romero, 1953 [1888], p. 1002), o escritor maranhense passa a ser considerado "um dos mais nítidos exemplares do povo, do genuíno povo brasileiro [...], o tipo do mestiço físico e moral, [pois] era filho de português e mameluca, ${ }^{13}$ [...], descendia das três raças que constituíram a população nacional e representava-lhes as principais tendências" (ibid., p. 1000). Como tal - garante o crítico -, estaria plena e naturalmente credenciado a realizar os ideais do nacionalismo literário: "A nacionalidade da literatura brasileira só pode ter uma solução: - acostar-se ao gênio, ao verdadeiro espírito popular, como ele sai do complexo de nossas origens étnicas" (ibid., p. 1006). José Veríssimo (1969 [1916], p. 163), por sua vez, embora introduzindo um cauteloso parece, referendou a ideia: “Gonçalves Dias é nas nossas letras um dos raros exemplos comprobatórios da falaz teoria da raça. Parece que nele se reuniam as três de que se formou o nosso povo" (grifo nosso). ${ }^{14}$ Não é diferente, por fim, o pensamento de Ronald de Carvalho (1968 [1919], p. 220), que credita o talento do poeta para

\footnotetext{
Gonçalves Dias, quanto à questão do negro, permaneceu na contramão da atitude majoritária entre os letrados românticos do País, pode ser feita igualmente com relação ao seu pensamento sobre a condição do índio na história nacional.

${ }^{12}$ Além dessas menções, Machado inclui em Americanas (1875) um poema intitulado "A Gonçalves Dias", em que celebra as glórias literárias do poeta maranhense, aludindo especialmente a situações e personagens de $O s$ timbiras.

${ }^{13}$ Segundo os dicionários, o termo mameluco, sinônimo de caboclo, designa o mestiço de índio e branco, ou de índio e mameluco. Ora, como Romero assume que Gonçalves Dias era produto das "três raças que constituíram a população nacional", e dado que o pai do poeta era branco, o elemento negro só podia provir de sua mãe, que, portanto, não seria mameluca, mas cafuza - como, aliás, a caracteriza José Veríssimo (1969 [1916], p. 163) -, isto é, mestiça de índio e negro. Lúcia Miguel-Pereira (1943, p. 13), com base no único traço que dela nos revela o biógrafo Antônio Henriques Leal (1868, p. XXIV; 1874, p. 6) - "mulher de cor acobreada" -, conclui que, "[n]a aparência, [ela] devia ser índia”. Roquette-Pinto (1948, p. 83), contudo, baseado nas feições do poeta conforme descritas por Henriques Leal, julga que ele poderia ser caboclo - isto é, mestiço de índio e branco -, e põe em dúvida que tivesse ascendência cafuza, concluindo que, como tantos maranhenses da mesma região, quanto ao "tipo antropológico" só se poderia dizer dele que era "obscur[us] et mixt[us] sanguinis" (de sangue obscuro e misto). Romero, porém, mesmo não havendo comprovação de que Gonçalves Dias tivesse o elemento negro em sua composição étnica, proclamou-o representante das três raças, o que convinha à maravilha para seu argumento. Desde então, à força de repetições, isso ficou sendo "verdade".

${ }^{14}$ Em outro ensaio, porém, Veríssimo (1977 [1901], p. 22) não faz qualquer ressalva à proclamação de Romero: "Gonçalves Dias, mestiço das três raças constituintes da nossa nacionalidade, [...] é o mais eminente produto da gente brasileira e o tipo mais universal dos seus representantes intelectuais."
} 
cantar o índio e a natureza do Brasil ao "sangue que lhe corria nas veias, e onde se cruzavam as tendências das três raças produtoras do mestiço brasileiro [...]."

Como se vê, nos pronunciamentos críticos antes analisados, proferidos até a década de 1860 , por conta da necessidade de preservar o decoro então vigente não se mencionam as origens do poeta, pois seria embaraçoso, para a sociedade da época, admitir que fosse mestiço um indivíduo reconhecido pela elite branca como grande escritor. A crítica pós-romântica e naturalista, porém, persistindo nos mesmos princípios do período romântico - nacionalismo e cor local como critérios de valor -, passa a dar relevo especial ao que chamaríamos hoje lugar de fala, e, assim, a condição de mestiço - e das três raças -, longe de constituir um estigma, transforma-se em credencial, que teria conferido a Gonçalves Dias legitimidade plena para "pintar [...] animados quadros da terra americana" (Romero, 1953 [1888], p. 1017), dada a "formação biológica do [seu] talento" (ibid., p. 1027), ou seu "brasileirismo [contido] na massa do sangue" (Veríssimo, 1969 [1916], p. 169).

Particularmente quanto a Os timbiras, apesar de menções ligeiras, ambos os críticos formulam juízos elogiosos. Romero (1953 [1888], p. 1010) resguarda-se de analisar o poema, alegando seu caráter de fragmento, mas valoriza em especial seus "pedaços líricos" (ibid., p. 1010) e força descritiva, transcrevendo-lhe um longo trecho do qual afirma: "É sóbrio; mas é belo; a simplicidade aqui não é filha da pobreza, mas sim da doce placidez do espírito" (ibid., p. 1019). Veríssimo (1969 [1916], p. 166], por sua vez, admitindo que a obra "cedia[...] ao preconceito do poema épico da tradição portuguesa", julga, contudo, que o fazia "com manifesta superioridade", pois apresentaria "muito maior vigor de idealização", "por ventura impulsado por um recôndito sentimento de sua alma de caboclo, avivado pela nostalgia do "filho do bosque". E conclui: "nenhum poeta brasileiro, em prosa ou verso, teve em grau igual ao de Gonçalves Dias o sentimento do nosso índio e do que lhe constituía a feição própria" (ibid., p. 167).

Quanto à crítica do século XX, até meados da década de 1950 ainda encontramos juízos presos ao "critério etnográfico" romeriano, vendo na poesia de Gonçalves Dias uma autenticidade que só sua condição de mestiço poderia explicar. É o que se lê em Haroldo Paranhos (1937) e Cassiano Ricardo (1969 [1956]). ${ }^{16}$ No entanto, cremos encontrar-se em Lúcia Miguel-Pereira (1942, p. 127) um ponto de inflexão na fortuna crítica do poeta, com sua tese de que a autenticidade do índio gonçalvino é antes estética e literária do que histórica e antropológica:

Que importa para a poesia, para a emoção despertada, que "I-Juca-Pirama" tenha ou não morrido de acordo com o rito dos selvagens? Que a marabá fosse ou não realmente desprezada pelos índios puros? Que as lutas dos timbiras com os gamelas sejam ou não históricas?

O fim da poesia não é a verdade formal - e sim a essencial - e Gonçalves Dias seria bem pobre poeta se os seus índios fossem meras ilustrações de teses etnográficas.

Mas, ao contrário, se nunca tivessem existido selvagens no Brasil, "I-Juca-Pirama", "Marabá" e Os timbiras e todas as Americanas conservariam inteiramente o seu valor poético, transmitiriam o mesmo entusiasmo, a mesma emoção.

\footnotetext{
${ }^{15}$ Embora as obras de José Veríssimo e Ronald de Carvalho ora citadas tenham sido publicadas respectivamente em 1916 e 1919, seus fundamentos conceituais são claramente oitocentistas, razão por que são ambas representativas desse segundo momento da recepção crítica de Gonçalves Dias.

${ }^{16}$ Em Bosi (1970, p. 114), Merquior (1977, p. 65) e Moisés (1985, p. 42), ainda se encontram referências ligeiras à condição de mestiço do poeta, tomada como dado sumária e remotamente pertinente para o juízo sobre sua obra.
} 
Não é outro o ponto de vista de Antônio Cândido, que firma de vez a virada da recepção crítica de Gonçalves Dias para o seu terceiro tempo. Assim, embora o professor Cândido, como é notório, permaneça identificado com a perspectiva nacionalista do Romantismo na sua tese sobre a literatura brasileira como sistema, ${ }^{17}$ rejeita o "critério etnográfico", tomando a produção literária não como registro verista ou manifestação emocionalmente autêntica, mas como criação ficcional esteticamente orientada. Para ele, pois, “[o] índio de Gonçalves Dias não é mais autêntico do que o de Magalhães ou o de Norberto pela circunstância de ser mais índio, mas por ser mais poético" (Cândido, 1971 [1959], v. 2, p. 85). ${ }^{18}$

Com relação especificamente a Os timbiras, são escassos os estudos analíticos feitos no século XX, tanto quanto, aliás, os datados do Oitocentos. Fora as referências sumárias, favoráveis - Paranhos (1937), Bandeira (1952) e Moisés (1985) - ou restritivas - Bosi (1970), Merquior (1977), Castello (1999),$-{ }^{19}$ considerações um pouco mais desenvolvidas só encontramos em Ackerman (1964 [1938]), Lúcia Miguel-Pereira (1943), Cassiano Ricardo (1969 [1956]) e Antônio Cândido (1971 [1959]).

Ackerman oferece minuciosa paráfrase do texto, descrevendo as ações canto a canto. Não deixa, porém, de fazer observações críticas pertinentes, centradas nas intenções do autor e nos processos narrativos, dramáticos e descritivos por ele acionados. Além disso, põe em relevo a dissidência constituída por Gonçalves Dias em relação à narrativa conciliadora que, na época, já se ia tornando hegemônica, representada pelo indianismo conforme praticado por autores como Joaquim Norberto e José de Alencar. A propósito dessa questão, assim se pronuncia o professor alemão:

Até certo ponto, essa obra [Os timbiras] pode também ser interpretada como protesto da natureza e de seus íncolas contra o conquistador, que, depois de roubar a terra ao vencido, escravizou o primitivo habitante. Às vezes os versos do poema soam como suspiros de saudade de tempos que se passaram, de lugares queridos que nunca se hão de rever, de florestas desaparecidas e de uma vida que se extinguiu. Talvez se possa chamar de pessimismo cultural a este sentimento que inspira ao poeta esse protesto. (Ackerman, 1964 [1938], p. 114.)

Bem menos extenso é o comentário de Lúcia Miguel-Pereira, que se atém a observações sobre a expectativa de Gonçalves Dias quanto ao poema, fornece os dados históricos em que se baseia o enredo e especula sobre os motivos por que o poeta não o concluiu. ${ }^{20}$ No mais, formula um juízo de valor, reconhecendo na composição mérito apenas relativo: "Há [...] majestade e sopro épico no tom geral, porém não aquela grandeza que empolga e subjuga - a marca da epopeia. Mas é inegável que, se está longe de ser uma Ilíada, encerra trechos realmente inspirados sobre a natureza, sobre a vida e os costumes primitivos" (Miguel-Pereira, 1943, p. 129).

\footnotetext{
${ }^{17}$ Cf.: "[M] e coloquei deliberadamente no ângulo dos nossos primeiros românticos [...]. Esses críticos conceberam a literatura do Brasil como expressão da realidade local e, ao mesmo tempo, elemento positivo na construção nacional" (Cândido, 1971 [1959], v. 1, p. 25).

${ }^{18} \mathrm{Na}$ sequência do trecho citado na nota anterior, lê-se: "Achei interessante estudar o sentido e a validade histórica dessa velha concepção cheia de equívocos [isto é, a concepção dos nossos primeiros românticos], [...] revendo-a na perspectiva atual" (Cândido, 1971 [1959], v. 1, p. 25). A "perspectiva atual”, obviamente, é a do Modernismo, que, como se sabe, vê o discurso literário muito mais como produto da imaginação do que como documentação de fatos ou resultado de determinismos.

${ }^{19}$ Menção ligeira ao poema encontra-se também em Nélson Werneck Sodré e Antônio Soares Amora. Sodré (1969 [1938], p. 291) afirma, sem apresentar qualquer argumento, que com "Os timbiras [...] o indianismo ganharia popularidade no Brasil [...]”, o que é de estranhar, pois o texto está longe de prestar-se a leitura fácil. Amora (1969 [1967], p. 141), por seu turno, o qualifica como "o maior poema indianista" do autor, não ficando claro se "maior" quanto à extensão ou quanto ao valor literário.

${ }^{20}$ Ver nota 1.
} 
Cassiano Ricardo, por sua vez, parte de um resumo do enredo, a que se segue análise basicamente estilística do texto, não sem concessões a muito impressionismo, o que transparece, por exemplo, na avaliação crítica que faz da composição: "O poema [...] se desenrola vigoroso, salpicado de trechos líricos admiráveis. A narrativa é cheia de cor e movimento, não obstante o verso medido, o verso branco"21 (Ricardo, 1969 [1956], p. 87).

Por fim, Antônio Cândido, em sua análise, avalia muito negativamente o poema, chegando a afirmar que a publicação dos quatro cantos "depõe contra o [...] critério [do poeta]" (1971 [1959], v. 2, p. 93). Assim, considera Os timbiras "poesia dura, pouco inspirada", e, "como estrutura, confuso, prolixo, inferior ao Caramuru e o Uraguai", sendo "o verso não raro desarmonioso e prosaico" (ibid., p. 93). Ameniza, porém, suas severas restrições ao poema, julgando "tratar-se mais de um malogro épico, no sentido estrito, do que poético [...], pois as partes líricas, marginais à narrativa, são frequentemente admiráveis, contando-se algumas entre o que de melhor escreveu" (ibid., p. 94).

Até esse terceiro tempo se estende a história da recepção crítica de Gonçalves Dias, e mais particularmente do seu projeto de epopeia apenas parcialmente realizado. No entanto, para além da parte por assim dizer consolidada que essa história apresenta, é possível entrever-se o despontar de um novo momento nesse percurso, configurado em contribuições mais recentes: Gentis guerreiros: o indianismo de Gonçalves Dias (1988), de Cláudia Neiva de Matos, e Gonçalves Dias: o poeta na contramão - literatura e escravidão no Romantismo brasileiro (2010), de Wilton José Marques. O primeiro estudo dedica-se a analisar, para usarmos os termos do próprio autor, suas "poesias americanas", isto é, o subconjunto de sua obra constituído pelas composições indianistas. O segundo, por sua vez, embora não traga subsídios diretos para a nossa questão específica - Os timbiras -, pois toma por objeto o fragmento de prosa poética Meditação (1846), consagrado a encenar as tensões étnicas entre negros e brancos no Brasil escravocrata, julgamos imprescindível referir, à medida que constitui marco importante de um momento novo nas interpretações do escritor maranhense.

Gentis guerreiros propõe-se estudar as relações entre ideologia e estética na obra do poeta, rejeitando o que a autora chama "visões totalizantes". Com esse objetivo, pelo próprio vocabulário técnico que mobiliza - no qual ocupam lugar destacado termos como "etnocentrismo", "construção cultural", "Diferença", "Semelhança", "Mesmo" -, o ensaio se alinha com os estudos culturais, prefigurando tendência que só faria fortalecer-se na universidade brasileira nas três últimas décadas. O estudo conclui pela existência de um projeto social e político conservador subjacente à obra poética e histórico-etnográfica de Gonçalves Dias: no fundo, mediante dissimulações estetizantes de uma "ideologia aristocrática, feudal, elitista, [...], descontente com a 'desordem política' de seu tempo" (Matos, 1988, p. 82), tanto a poesia como os estudos científicos do autor apontariam para a urgência de "restabelecer a Moral e a Ordem do passado na modernidade burguesa decaída" (ibid., p. 81), pelo exemplo da sociedade indígena, idealizada pela combinação da "mítica do cavaleiro feudal à do bom selvagem" (ibid., p. 28). Breve análise de Os timbiras é conduzida nessa chave, sendo o poema

\footnotetext{
${ }^{21}$ Curiosa essa restrição, como se o verso branco em si mesmo fosse um senão técnico ou poético. Aliás, quanto ao manejo do verso branco por Gonçalves Dias, Manuel Bandeira (1952; in Dias, 1959, p. 74) não economiza elogios, em sua análise da poética do autor: "Não quero ir adiante sem assinalar o domínio magistral de Gonçalves Dias sobre os decassílabos brancos, como é de ver n'Os timbiras e em 42 poemas dos Cantos. Especialmente na introdução e em passagens descritivas d'Os timbiras, em 'A Sua Voz', 'Leito de Folhas Verdes' e 'Se se morre de amor' atingiu uma flexibilidade, um jogo de cadências uma harmonia de força e leveza jamais ultrapassada em nossa língua, quer antes, por um Garrett na famosa invocação do poema Camões, quer depois, por um Fagundes Varela no soberbo 'Cântico do Calvário'." Machado de Assis (1973a [1879], p. 814) tem a mesma opinião, assinalando o vigor especial que ganham os versos brancos nos poemas de Gonçalves Dias.
} 
considerado "não [...] dos maiores êxitos do indianismo gonçalvino" (ibid., p. 31), no que ele se diferenciaria das demais composições congêneres do autor, avaliadas como "lindos poemas" (ibid., p. 83), não obstante o fato de que, neles, "a identidade do Outro desaparece, absorvida pela imagem projetada do Mesmo [...]" (ibid., p. 83).

Gonçalves Dias: o poeta na contramão, por seu turno, também se inscreve no âmbito dos estudos culturais, na sua proposta de, como diz o segundo segmento do subtítulo da obra, analisar as relações entre "literatura e escravidão no Romantismo brasileiro". A posição do autor, contudo, com relação ao significado político da obra de Gonçalves Dias, diverge completamente do que se lê em Gentis guerreiros. Assim, em vez de um pensamento conservador, Gonçalves Dias, muito pelo contrário, teria produzido "uma obra literária que se caracteriza não apenas por ser avessa às expectativas românticas oficiais, mas, sobretudo, por trazer em si todos os elementos necessários à explicitação das várias mazelas sociais do Brasil oitocentista, o que, por tabela, traduz-se num gesto inconteste de denúncia" (Marques, 2010, p. 267).

Não é nosso propósito iniciar aqui o debate sugerido por essas leituras, que, ao mesmo tempo que se aproximam por um propósito comum - examinar os aspectos ideológicos implicados pela parte da obra de Gonçalves Dias dedicada aos dois segmentos politicamente não hegemônicos na formação da sociedade brasileira: ameríndios e africanos -, chegam, como se vê, a resultados tão divergentes. No entanto, para a configuração plena de um quarto tempo na história da recepção crítica de Gonçalves Dias - que, a nosso ver, esses dois estudos inauguram - essa controvérsia constitui ponto de partida incontornável. Da nossa parte, por ora, para não nos transviarmos do nosso objetivo, digamos apenas que, como não parece possível que o poeta tenha sido reacionário no que tange à questão do índio e progressista no que concerne à do negro, parece-nos que o simples fato de ter-se dedicado a essas duas etnias em seus empenhos intelectuais, num tempo em que a sociedade brasileira se mostrava tão hostil para com ambas (certamente, mais ainda para com o negro), já indicia sua posição avançada em matéria de pensamento social. No mais, reconhecendo embora que esse problema precisa ser mais bem estudado, parece-nos mais consistente a tese do poeta na contramão do que a dos gentis guerreiros. ${ }^{22}$

Voltemos, porém, a Os timbiras, a fim de arrematarmos nossas considerações, fixandonos agora nas motivações e consequências da opção de Gonçalves Dias pela forma da epopeia.

\footnotetext{
${ }^{22}$ Se dúvidas houver sobre a assunção por Gonçalves Dias de um ponto de vista contrário ao da história oficial a respeito da colonização, aí incluída a catequese, basta ter em conta a seguinte veemente condenação do processo, num seu artigo de 1850: “[...] as primeiras páginas da história do Brasil estão alastradas de sangue, mas de sangue inocente, vilmente derramado! O único motivo de quase todos os fatos que aqui se praticaram durante três grandes séculos foi a cobiça; cobiça infrene, insaciável [...]. Se vos perguntarem por que tantos riscos correram, por que se afrontaram tantos perigos, por que se subiram tantos montes, por que se exploraram tantos rios, por que se descobriram tantas terras, por que assolaram tantas tribos; dizei-o, e não mentireis: - foi por cobiça. Era por cobiça que os governadores vinham a estas terras, tão remotas, onde nenhuma glória os esperava; era por cobiça que os próprios missionários deixavam a frisa e a orla das roupetas nestas florestas sem caminho, por que tantas privações passavam, por que sofreram tantos martírios" (Dias, 1850, p. 28). Por outro lado, nesse mesmo artigo revela idealização romântica do índio: "O primeiro tópico de que havemos de tratar na história do Brasil é dos índios. [...] Não digamos [...] que eram um povo bruto e feroz, nem os apreciemos pelos que hoje conhecemos. Não degeneraram ao contacto com a civilização, porque esta não pode envilecer; mas embruteceram à força de servidão, perderam a dignidade, o caráter próprio, e o heroísmo selvagem, que tantos prodígios cometeu e perfez. Vede o que fizeram e dizei se não há grandeza e magnanimidade nessa luta que sustentam há mais de três séculos, opondo a flecha à bala, e a tacape sem gume à espada d'aço refinada. [...] vereis o que são, o que fazem, o de que são capazes: [...] corajosos e infatigáveis, pertinazes no seu propósito, atilados na sua execução, quase sempre poetas, heróis algumas vezes" (ibid., p. 28-29).
}

Rev. Bras. Lit. Comp. Niterói, v. 22, n. 40, pp. 56-72, mai. /ago. 2020

https://doi.org/10.1590/2596-304X20202240ras 
Vimos que o poeta concebeu o projeto da obra por volta de 1844 . Nessa altura, o prestígio da poesia épica ainda se mantinha elevado no Brasil, e de certo modo assim se conservaria até mais ou menos o início da década de 1870. Comprovam o fato os elogios de que o gênero era objeto sistemático nos compêndios escolares de poética então em uso, os quais, ao mesmo tempo, mostravam-se bastante reticentes em relação ao romance, a espécie narrativa em ascensão na época. ${ }^{23}$ Ora, o estudante Gonçalves Dias - como, de resto, as sucessivas gerações de alunos brasileiros do Oitocentos - certamente foi leitor assíduo dessas fontes de informação, cuja autoridade muito deve ter contribuído para a definição de suas preferências literárias.

Se isso é perfeitamente compreensível, surpreende um pouco, contudo, que o poeta não se tenha deixado abalar, em sua estima pela epopeia, com o desgaste crescente dessa modalidade de poesia, correlativa e proporcional à ascensão do gosto pelo romance. Como se sabe, um marco nesse processo se deu em 1856, quando da publicação de A Confederação dos Tamoios, de Gonçalves de Magalhães, alvo da famosa demolição crítica empreendida por José de Alencar naquele mesmo ano, entre cujos argumentos principais figurava a ideia de que o romance, e não a epopeia, constituía a forma por excelência adequada para a nascente literatura brasileira. ${ }^{24} \mathrm{Na}$ ocasião da ruidosa polêmica suscitada pelas "Cartas" de Alencar, por sinal, Gonçalves Dias escreveu de Lisboa a D. Pedro II, agradecendo ao monarca por lhe ter enviado um exemplar do livro de Magalhães. Na carta, confessa não ter gostado do poema, mas refere um episódio em que tomou as dores do autor:

Estávamos uma meia dúzia em casa do Sr. [Alexandre] Herculano, e eu tratava de defender o nosso poeta, que estava ali sendo vítima de exageradas censuras: exageradas, digo, quando se aprecia o seu merecimento em geral. [...]

O Sr. Herculano, que não entrara na discussão, abriu o volume, leu duas coisas, e achando alguma que lhe não agradava, voltou-se para mim com alguma vivacidade, mandando que matasse ao meu colega.

Disse-me ele: 'Mate-me esse homem. Mate-mo.'

E conclui: "Era a mesma voz que eu tinha ouvido no começo da minha carreira, e como da primeira vez, rompendo espontânea da abundância do coração. Vim para casa ler os borrões do meu poema. Estou com mais medo, mas também com mais vontade de o acabar" (Dias, 2007 [1856], p. cxlii-cxliii). Assim, seu juízo negativo sobre o poema de Magalhães nada tinha a ver com a circunstância de tratar-se de uma epopeia, sendo antes motivado, como ele declara na mesma carta, pela "versificação frouxa, [...] imagens pouco felizes, [...] linguagem por vezes menos grave, menos própria de tal gênero de composições" (ibid., p. cxl). Persistia inabalável, portanto, seu apreço pelo épico, o que explica a retomada dos "borrões do [seu] poema" - Os timbiras, seguramente - e a "vontade de o acabar", temeroso do julgamento de Herculano, mas ao mesmo tempo estimulado pela possibilidade de merecer novamente os aplausos do escritor português, a exemplo do que ocorrera dez anos antes, quando publicara os seus Primeiros

\footnotetext{
${ }^{23}$ Esses livros adotados no sistema escolar brasileiro oitocentista ou sequer tratam do romance ou exaltam a epopeia em detrimento deste. Entre eles, podemos citar: Lições de eloquência nacional (edições em 1846, 1851 e 1864), de Miguel do Sacramento Lopes Gama; Sinopse da poética nacional (1859, com edições, de títulos alterados, em 1861, 1870 e 1879); Postilas de retórica e poética (edições em 1872, 1877 e 1885). Mas é numa publicação já do século XX, embora toda concebida no espírito de suas antecessoras oitocentistas, que encontramos o mais explícito elogio da epopeia e correlativa condenação do romance: "O romance não é, como a epopeia donde deriva, escola de heroísmo e idealização. Antes, deprime muito mais que eleva. Ninguém, portanto, deverá ler romance algum sem primeiro informar-se, junto a pessoa autorizada, se essa leitura é conciliável com as restrições intangíveis da consciência" (Magne, 1935, p. 278).

${ }^{24}$ Relembremos: "A forma com que Homero cantou os gregos não serve para cantar os índios; o verso que disse as desgraças de Troia, e os combates mitológicos não pode exprimir as tristes endechas do Guanabara, e as tradições selvagens da América" (Alencar, 1960 [1856], p. 877-878).
}

Rev. Bras. Lit. Comp. Niterói, v. 22, n. 40, pp. 56-72, mai. /ago. 2020

https://doi.org/10.1590/2596-304X20202240ras 
cantos. ${ }^{25}$ A parte até então composta do texto - os quatro cantos iniciais - o poeta os daria a público logo no ano subsequente, 1857, mas, dessa vez, provavelmente para sua decepção, Herculano não se pronunciou.

No entanto, em boa medida, parece claro que um dos motivos por que os juízos críticos acerca do poema ficaram muito abaixo das expectativas do autor - além, naturalmente, da circunstância de a obra ter permanecido incompleta - é justamente o anacronismo do seu gênero. Nesse sentido, pronunciaram-se José Veríssimo (1969 [1916], p. 166), que afirma, em tom de reparo, ter a composição "cedi[do] ao preconceito do poema épico da tradição portuguesa", bem como Haroldo Paranhos (1937, p. 98), segundo o qual "sua feição épica [estava] em desacordo com o momento em que foi produzid[a]". Por outro lado, diversos analistas assinalam certo desencontro entre o talento do poeta e a forma épica, tanto que Os timbiras se destacariam justamente por suas passagens líricas, ou mesmo só se salvariam por elas. Compartilham dessa opinião Sílvio Romero (1953 [1888], p. 1010), Manuel Bandeira (1952, p. 225), Cassiano Ricardo (1969 [1956], p. 87 e 90), e Antônio Cândido (1971 [1959], v. 2, p. 94) afirma - citemos o trecho mais uma vez - "tratar-se mais de um malogro épico, no sentido estrito, de que um malogro poético, [...] pois as partes líricas, marginais à narrativa, são frequentemente admiráveis, contando-se algumas entre o que de melhor escreveu". De fato, tem razão o crítico, ao assinalar que "o poema, como estrutura, [é] confuso, prolixo", apresentando "entrecho [...] delineado sem muita clareza", ${ }^{26}$ bem como "cenas [...] longas e redundantes" (ibid., p. 94). Os momentos líricos, porém, são, na verdade, conforme diz Cândido, "admiráveis", como se verifica, por exemplo, nas aberturas dos cantos segundo e terceiro, respectivamente descrições do anoitecer e da aurora, executadas à perfeição, mediante a absorção de traços românticos (cor local - a ema, a floresta, as selvas, o cáctus - e melancolia) pelos padrões neoclássicos adotados (verso branco e locus amoenus). Vejamos os trechos:

Desdobra-se da noite o manto escuro:

Leve brisa subtil pela floresta

Enreda-se murmura, - amplo silêncio

Reina por fim. Nem saberás tu como

Essa imagem da morte é triste e torva,

Se nunca, a sós contigo, a pressentiste ${ }^{27}$

Longe deste zunir da turba inquieta.

No ermo, sim; procura o ermo e as selvas...

Escuta o som final, o extremo alento,

Que exala em fins do dia a natureza!

\footnotetext{
${ }^{25}$ O ensaio de Alexandre Herculano sobre o livro - "Futuro literário de Portugal e do Brasil" - saiu em 1848, na Revista Universal Lisbonense. Tomado como consagração do autor, tal o prestígio intelectual de Herculano na época, o ensaio foi incluído por Gonçalves Dias na segunda edição dos Primeiros cantos, datada de 1857 , figurando desde então nas sucessivas edições da obra, à maneira de um prefácio ou apresentação.

${ }^{26}$ A confusão da estrutura e a falta de clareza da trama arguidas pelo crítico talvez possam pelo menos diminuir mediante um tratamento editorial melhor para o texto, que, entre outras possíveis providências, estabeleça um sistema de pontuação mais coerente e funcional, bem como adote recursos gráficos - como uso de travessão ou aspas - que permitam distinção clara e pronta entre o discurso do narrador e as falas dos personagens. Em face de tais imperfeições, e mesmo de erros que aparecem inclusive numa leitura sem compromissos com revisão (vejamse, nesse sentido, as duas notas subsequentes), é de estranhar o que assevera Antônio Houaiss num dos estudos constantes do volume Poesia completa que utilizamos para a elaboração deste trabalho: "Do ponto de vista da crítica textual, dita também ecdótica, a tradição - tradição é o termo técnico - do texto da quase totalidade dos poemas de Gonçalves Dias é altamente satisfatória” (in Dias, 1959, p. 79).

${ }^{27} \mathrm{Na}$ edição-fonte, "pressentisse". Suspeitando do erro, corrigimos, referendados, de resto, pela que se lê em outra edição que tínhamos à mão: Poesias de A. Gonçalves Dias. Nova ed. organizada e revista por J. Norberto de Souza Silva, e precedida de uma notícia sobre o autor e suas obras pelo cônego doutor Fernandes Pinheiro. Rio de Janeiro; Paris: Garnier, 1910 [1870]. Ver tomo II, p. 167.
} 
O pensamento, que incessante voa,

Vai do som à mudez, da luz às sombras

E da terra sem flor, ao céu sem astro.

Similha a fraca luz, qu'inda vacila

Quando, em ledo sarau, o extremo acorde

No deserto salão geme, e se apaga!

(Dias, 1959 [1857], p. 486.)

Era a hora em que a flor balança o cálix

Aos doces beijos da serena brisa,

Quando a ema soberba alteia o colo,

Roçando apenas o tapiz ${ }^{28}$ relvoso;

Quando o sol vem doirando os altos montes,

$\mathrm{E}$ as ledas aves à porfia trinam,

$\mathrm{E}$ a verde coma dos frondosos cerros

Move o perfume, que embalsama os ares;

Quando a corrente meio oculta soa

De sob o denso véu da parda névoa;

Quando nos panos das mais brancas nuvens

Desenha a aurora melindrosos quadros

Gentis ornados com listões de fogo;

Quando o vivo carmim do esbelto cáctus

Refulge a medo abrilhantado esmalte,

Doce poeira de aljofradas gotas,

Ou pó subtil de pérolas desfeitas.

Era a hora gentil, filha de amores,

Era o nascer do sol, libando as meigas,

Risonhas faces da luzente aurora!

Era o canto e o perfume, a luz e a vida,

Uma só coisa e muitas, - melhor face

Da sempre vária e bela natureza:

Um quadro antigo, que já vimos todos,

Que todos com prazer vemos de novo.

(ibid., p. 497.)

Enfim, conforme o tempo demonstraria, Os timbiras, talvez até mesmo se tivesse sido publicado na íntegra, estava destinado ao esquecimento, a exemplo, aliás, de outras epopeias brasileiras do século XIX, que há muito tempo ninguém lê, e que jazem nas estantes como letras mortas, em boa medida como decorrência de sua inadaptação às circunstâncias da modernidade literária. É o caso não só de A Confederação dos Tamoios (1856), mas também de Os filhos de Tupã (1863), ${ }^{29}$ de José de Alencar, de Colombo (1866), de Manuel de Araújo Porto Alegre, e de $O$ Guesa ${ }^{30}$ de Joaquim de Sousândrade.

\footnotetext{
${ }^{28} \mathrm{Na}$ edição-fonte, "matiz". Suspeitando de que o correto seria "tapiz" (sinônimo poético de "tapete"), corrigimos com o referendo da mesma edição citada na nota anterior.

${ }^{29}$ Projeto abandonado pelo autor, cuja parte que chegou a ser escrita foi publicada postumamente, primeiro na Revista da Academia Brasileira de Letras (v. 1, números 1, 2 e 3, de julho de 1910 a janeiro de 1911), e depois, com acréscimos, no v. 4 da edição Obra completa (Rio de Janeiro: José Aguilar, 1959-1960. 4 v.).

${ }^{30} \mathrm{O}$ poema foi composto entre 1854 e 1888 , e publicado de modo algo caótico entre 1866 (ou 1868) e 1888. O retorno a ele, determinado pelo volume ReVisão de Sousândrade, publicado em 1964, com organização de Augusto e Haroldo de Campos, e com a colaboração de Erthos A. de Souza e Luiz Costa Lima, sustentou-se por pouco tempo, tendo representado muito mais um episódio do movimento concretista - a valorização dos arrojos de 
Quanto a Gonçalves Dias, permanece lembrado, lido e estimado pelos seus; mas não o poema em que tão custosa e persistentemente trabalhou anos a fio, alimentando seu desejo de glória literária, e sobre o qual, esperançoso, declarou: "criarei alguma cousa que espero em Deus, os nossos não esquecerão".

\section{REFERÊNCIAS}

ACKERMANN, Fritz. A obra poética de Gonçalves Dias. Trad. Egon Schaden. São Paulo: Conselho Estadual de Cultura, 1964. [1938]

ALENCAR, José de. Cartas sobre A Confederação dos Tamoios". In: Obra completa. Introdução geral de M. Cavalcânti Proença. Rio de Janeiro: José Aguilar, 1960. v. 4. [1856]

AMORA, Antônio Soares. O Romantismo: 1833-1838/1878-1881. 3. ed. São Paulo: Cultrix, 1969. [1967]

ASSIS, Machado. A Gonçalves Dias. In: Obra completa. Organizada por Afrânio Coutinho. Com estudos de Manuel Bandeira, Tristão de Ataíde, Gustavo Corção, Afrânio Coutinho e Eugênio Gomes. Rio de Janeiro: José Aguilar, 1973. V. 3, p. 130-133. [1875]

A nova geração. In: Obra completa. Organizada por Afrânio Coutinho. Com estudos de Manuel Bandeira, Tristão de Ataíde, Gustavo Corção, Afrânio Coutinho e Eugênio Gomes. Rio de Janeiro: José Aguilar, 1973. V. 3, p. 809-836. [1879]

Notícia da atual literatura brasileira: instinto de nacionalidade. In: . Obra completa. Organizada por Afrânio Coutinho. Com estudos de Manuel Bandeira, Tristão de Ataíde, Gustavo Corção, Afrânio Coutinho e Eugênio Gomes. Rio de Janeiro: José Aguilar, 1974. v. 3, p. 801-809. [1873]

BANDEIRA, Manuel. Gonçalves Dias: esboço biográfico. Rio de Janeiro: Pongetti, 1952.

Gonçalves Dias: poesia. 7. ed. Revisão crítica, em consulta com o autor, por Maximiano de Carvalho e Silva. Rio de Janeiro: Agir, 1975.

BOSI, Alfredo. História concisa da literatura brasileira. São Paulo: Cultrix, 1970.

CÂNDIDO, Antônio. Formação da literatura brasileira: momentos decisivos. 4. ed. São Paulo: Martins, 1971. 2 v. [1959]

CARVALHO, Ronald de. Pequena história da literatura brasileira. 13. ed. Prefácio de Medeiros e Albuquerque. Rio de Janeiro: F. Briguiet, 1968. [1919]

CASTELLO, José Aderaldo. A literatura brasileira: origens e unidade. São Paulo: Edusp, 1999. v. 1 .

DIAS, Gonçalves. Carta a D. Pedro II datada de 13/09/1856. In: MAGALHÃES, Domingos José Gonçalves de. A Confederação dos Tamoios. Organização de Maria Eunice Moreira e Luís Bueno. Curitiba: Ed. UFPR, 2007. p. cxl-cxliii. [1856]

linguagem do poeta maranhense, tomados como afins a procedimentos técnicos próprios da poesia concreta - do que um interesse pelo poema na sua especificidade histórica. 
Poesia completa: e prosa escolhida. Com estudos de Manuel Bandeira, Antônio Houaiss e Alexandre Herculano. Rio de Janeiro: José Aguilar, 1959.

Reflexões sobre os Anais históricos do Maranhão por Bernardo Pereira Berredo. Guanabara: Revista Artística, Científica e Literária, Rio de Janeiro, t. 1, 1850, p. 25-30 e 5863.

GUIMARÃES, Bernardo. À morte de Gonçalves Dias: canto elegíaco. In: $O$ índio Afonso; seguido de "A morte de Gonçalves Dias: canto elegíaco". Rio de Janeiro; Paris: H. Garnier, p. 123-142. [1873]

[GUIMARÃES, Bernardo]. Os timbiras, poema do Sr. A. G. Dias. A Atualidade: Jornal Político, Literário e Noticioso, Rio de Janeiro, ano I, n. 55, 8 out. 1859, p. 3.

56,15 out. 1859, p. 2.

A Atualidade: Jornal Político, Literário e Noticioso, Rio de Janeiro, ano I, n. 57, 26 out. 1859 p. 2-3.

A Atualidade: Jornal Político, Literário e Noticioso, Rio de Janeiro, ano I, n. A Atualidade: Jornal Político, Literário e Noticioso, Rio de Janeiro, ano I, n. 58,31 out. 1859 , p. $2-3$.

GULLAR, Ferreira. Gonçalves Dias. Rio de Janeiro: Academia Brasileira de Letras; São Paulo: Imprensa Oficial do Estado, 2010.

LEAL, Antônio Henriques. Biografia de A. Gonçalves Dias. In: DIAS, A. Gonçalves. Obras póstumas. Precedidas de uma notícia de sua vida e obras pelo doutor Antônio Henriques Leal. São Luís do Maranhão: [s.n.], 1868. V. 1, p. XI-LXIV.

XVI: Antônio Gonçalves Dias. In: Panteon maranhense: ensaios biográficos dos maranhenses ilustres já falecidos. Lisboa: Imprensa Nacional, 1874. v. 3.

MACEDO, Joaquim Manuel de. A semana. Jornal do Comércio, Rio de Janeiro, ano XXXII, n. 335,6 dez. 1857 , p. 1 .

MAGNE, Augusto, S. J. Princípios elementares de literatura: volume primeiro - teoria literária. São Paulo: Cia. Ed. Nacional, 1935.

MARQUES, Wilton José. Gonçalves Dias - o poeta na contramão: literatura e escravidão no Romantismo brasileiro. São Carlos, SP: Edufscar, 2010.

MATTOS, Cláudia Neiva de. Gentis guerreiros: o indianismo de Gonçalves Dias. São Paulo: Atual, 1988.

MERQUIOR, José Guilherme. De Anchieta a Euclides: breve história da literatura brasileira. Rio de Janeiro: José Olympio, 1977. 
MONTELlO, Josué. Gonçalves Dias: ensaio biobibliográfico. Rio de Janeiro: Academia Brasileira de Letras, 1942.

MIGUEL-PEREIRA, Lúcia. A vida de Gonçalves Dias: contendo o Diário inédito da viagem de Gonçalves Dias ao Rio Negro. Rio de Janeiro: José Olympio, 1943.

MOISÉS, Massaud. História da literatura brasileira. São Paulo: Cultrix, 1985. v. 2 (Romantismo).

MORAES, Jomar. Gonçalves Dias: vida e obra. São Luís: Alumar, 1998.

OTAVIANO, Francisco. Páginas menores. Correio Mercantil, Rio de Janeiro, n. 334, 7 dez. 1857, p. 1.

PARANHOS, Haroldo. História do Romantismo no Brasil: 1830-1850. São Paulo: Cultura Brasileira, 1937.

PINHEIRO, [Joaquim Caetano] Fernandes. Curso elementar de literatura nacional. 2. ed. melhorada. Rio de Janeiro: B.L. Garnier, 1883 [1862].

. Notícia sobe a vida e a obra d'Antônio Gonçalves Dias. In: DIAS, Gonçalves A. Poesias. 7. ed. Nova ed. organizada e revista por J. Norberto de Sousa Silva e precedida de uma notícia sobre o autor e suas obras pelo cônego doutor Fernandes Pinheiro. Rio de Janeiro; Paris: Garnier, 1910 [1870]. v. 1, p. 21-37.

. Resumo de história literária. Rio de Janeiro: B. L. Garnier, s.d.. v. 2. [1873]

REIS, Francisco Sotero. Curso de literatura portuguesa e brasileira: professado por Francisco Sotero dos Reis no Instituto de Humanidades da Província do Maranhão [...]. Maranhão: [s.n.], 1866-1873. v. 4 (1868) e v. 5 (1873).

RICARDO, Cassiano. Gonçalves Dias e o indianismo. In: COUTINHO, Afrânio, org.. A literatura no Brasil. 2. ed. Rio de Janeiro: Sul Americana, 1969. v. 2, p. 65-129. [1956]

ROMERO, Sílvio. História da literatura brasileira. 5. ed. Organizada e prefaciada por Nélson Romero. Rio de Janeiro: José Olympio, 1953. v. 3. [1888]

ROQUETTE-PINTO, E[dgar]. Gonçalves Dias e os índios. In: SOARES, José Carlos de Macedo et alii. Gonçalves Dias: conferências da Academia Brasileira. Rio de Janeiro: Academia Brasileira de Letras, 1948, p. 83-93.

SODRÉ, Nélson Werneck. História da literatura brasileira: seus fundamentos econômicos. 5. ed. Rio de Janeiro: Civilização Brasileira, 1969. [1938]

TREECE, David. Exilados, aliados, rebeldes: o movimento indianista, a política indigenista e o estado-nação imperial. Tradução de Fábio Fonseca de Melo. São Paulo: Nankin; Edusp, 2008. [2000]

VERÍSSIMO, José. Gonçalves Dias. In: Estudos de literatura brasileira: $2 .^{\text {a }}$ série. Belo Horizonte: Itatiaia; São Paulo: Edusp, 1977, p. 19-26. [1901]. 
História da literatura brasileira: de Bento Teixeira (1601) a Machado de Assis (1908). 5. ed. Prefácio de Alceu de Amoroso Lima. Rio de Janeiro: José Olympio, 1969. [1916]

WOLF, Ferdinand. O Brasil literário: história da literatura brasileira. Tradução, prefácio e notas de Jamil Almansur Haddad. São Paulo: Companhia Ed. Nacional, 1955. [1863]

Roberto Acízelo de Souza - Doutor em Letras pela Universidade Federal do Rio de Janeiro, pesquisador do CNPq e Cientista do Nosso Estado (FAPERJ), com pós-doutorado na Universidade de São Paulo, lecionou na Universidade Federal Fluminense, sendo atualmente professor titular na Universidade Estadual do Rio de Janeiro. Seus livros mais recentes são Portugal segundo o Brasil (2018), E a literatura, hoje? Estudos de crítica, história e teorias literárias (2018), Teoria da literatura: trajetória, fundamentos, problemas (2018) e Historiografia da literatura brasileira: introdução (2018). https://orcid.org/0000-0003-06075911.

Submetido em 16/02/2020

Aceito em 02/04/2020 